\title{
The importance of patency in patients with critical limb ischemia undergoing endovascular revascularization for infrapopliteal arterial disease
}

\author{
Frederic Baumann', Christoph Ozdoba ${ }^{2}$, Ernst Gröchenig ${ }^{3}$ and Nicolas Diehm ${ }^{3,4}$ * \\ ${ }^{1}$ Miami Cardiac and Vascular Institute, Baptist Hospital, Miami, FL, USA \\ ${ }^{2}$ Clinical and Interventional Neuroradiology, University Hospital Bern, Bern, Switzerland \\ ${ }^{3}$ Clinical and Interventional Angiology, Kantonsspital Aarau, Aarau, Switzerland \\ ${ }^{4}$ University of Applied Sciences Furtwangen, Villingen-Schwenningen, Germany
}

Edited by:

Marianne Brodmann, Medical

University Graz, Austria

\section{Reviewed by:}

Erich Minar, Medical University of

Vienna, Austria

Heiko Uthoff, University Hospital

Basel, Switzerland

Martin Werner, Medical University of

Vienna, Austria

*Correspondence:

Nicolas Diehm, Clinical and Interventional Angiology,

Kantonsspital Aarau, Tellstrasse, 5001

Aarau, Schweiz, Switzerland

e-mail:nicolas.a.diehm@gmail.com
Critical limb ischemia (CLI) represents the most severe form of peripheral arterial disease (PAD) and frequently occurs in medically frail patients. CLI patients frequently exhibit multisegmental PAD commonly including the tibial arterial segment. Endovascular therapy has been established as first-line revascularization strategy for most CLI patients. Restenosis was reported to occur in up to more than two-thirds of CLI patients undergoing angioplasty of complex tibial arterial obstructions. Nevertheless, favorable clinical outcomes were observed for infrapopliteal angioplasty when compared with bypass surgery, despite higher patency rates for the latter. Based on these observations, infrapopliteal patency was considered to be only of secondary importance upon clinical outcomes in CLI patients. In contrast to these earlier observations, however, recent findings from two randomized clinical trials indicate that infrapopliteal patency does impact on clinical outcomes in CLI patients. The purpose of the present manuscript is to provide a critical reappraisal of the present literature on the clinical importance of tibial arterial patency in CLI patients undergoing endovascular revascularization and to discuss utility and limitations of currently available anti-restenosis technologies.

Keywords: critical limb ischemia, below the knee, endovascular revascularization, patency

\section{INTRODUCTION}

Critical limb ischemia (CLI) represents a medically frail subgroup of patients presenting with the most severe form of peripheral arterial disease $(\mathrm{PAD})(1-3)$. In these patients, revascularization is among the cornerstones of treatment and aims at the prevention of amputation and improvement of quality of life $(1,4,5)$. CLI patients frequently present with multilevel PAD including complex obstructions of tibial arteries and, thus, frequently require challenging revascularization procedures. Endovascular therapy has been established as a first-line revascularization strategy for most CLI patients $(5,6)$ since it was shown to provide comparable clinical outcomes when compared with bypass surgery, despite higher patency rates for the latter $(5,7)$. Based on these observations, the tide over concept was established assuming that tibial arterial patency was mandatory only during the process of wound healing but not thereafter for the maintenance of skin integrity and resolution of CLI symptoms (7-9). More recent studies, however, have stressed the importance of tibial patency upon clinical outcomes in CLI patients, thereby challenging the tide over concept (10-13).

The purpose of this review article is to provide a critical reappraisal of the importance of tibial arterial patency on clinical outcomes in CLI patients. Moreover, we seek to analyze recently performed trials on endovascular revascularization for tibial PAD and to stress their applicability to everyday clinical practice.

\section{METHODS}

A comprehensive literature research was performed based on Pubmed database. All studies included in the meta-analysis by Romiti et al. (7) were acquired using Pubmed and analyzed thereafter (researched April 2013). In addition, we reviewed literature for completed and ongoing randomized trials on drug-eluting stents (DESs) and drug-eluting balloon (DEB) versus bare metal stent (BMS) and/or plain-old balloon angioplasty (POBA) for tibial arterial revascularization. The latter literature research was based on Pubmed (www.pubmed.org, last accessed on March 13, 2014) and clinicaltrials.gov (last accessed on April 28, 2014) entries.

\section{INCIDENCE OF TIBIAL ARTERIAL RESTENOSIS AFTER ANGIOPLASTY}

Restenosis remains the major drawback in CLI patients undergoing endovascular therapy of tibial arterial obstructions. Various studies reported tibial restenosis to occur in up to more than twothirds of patients undergoing angioplasty of complex tibial arterial obstructions $(10-12,14,15)$. Within a prospective study, Schmidt and colleagues evaluated the incidence of tibial arterial restenosis in CLI patients undergoing POBA. Restenosis was defined as a lumen compromise $\geq 50 \%$ on serial angiography after 3 months (15). A total of 58 CLI patients (77 limbs) with a mean tibial lesion length of $184 \mathrm{~mm}$ were analyzed. In that cohort, binary 
restenosis was observed in $68.8 \%$ of limbs. Similar results were observed by Liistro and coworkers within the DEBATE-BTK trial (10) comparing POBA versus DEB. In that study, binary restenosis was assessed by angiography and defined as a reduction of luminal diameter $>50 \%$ or by duplex sonography defined as a peak systolic velocity index $\geq 2.5$. After 1 year, tibial restenosis was observed in $74 \%$ in the POBA (74 limbs, mean lesion length: $131 \mathrm{~mm}$ ) and $27 \%$ in the DEB group (74 limbs, mean lesion length: $129 \mathrm{~mm}$ $[P<0.001])$. In addition, Iida and coworkers analyzed the incidence of tibial restenosis and its impact on clinical outcomes in CLI patients after POBA in a total of 63 patients (12). Restenosis was evaluated angiographically and defined as a reduction of luminal diameter $\geq 50 \%$. After 3 months, tibial restenosis was observed in $74 / 102(73 \%)$ of treated lesions. Of note, no detailed information on tibial lesion length was provided in that study, although tibial lesion length was shown to be indicative for the risk of tibial restenosis (16).

\section{IMPACT OF TIBIAL ARTERIAL PATENCY ON CLINICAL OUTCOMES IN CLI}

Despite the high rates of tibial restenosis subsequent to POBA, endovascular revascularization is considered the first-line treatment strategy for most CLI patients $(5,6)$. Until now, the BASIL trial was the first and only trial randomly comparing endovascular therapy with open surgery in CLI patients undergoing infrainguinal revascularization (5). In that trial, a total of 452 patients (224 angioplasty, 228 surgery) were analyzed for amputation-free survival. After 1 year, an amputation-free survival was obtained in 68 versus $71 \%$ and after 3 years 57 versus 53\% comparing bypass surgery with angioplasty $(P>0.05)$. This observation was underlined by a frequently cited meta-analysis by Romiti et al. (7). In that meta-analysis, the impact of tibial patency on clinical outcomes comparing endovascular versus surgical revascularization strategies in CLI was scrutinized. For that reason, a total of 30 studies including 2646 patients were analyzed (Table 1). Primary patency was $58.1,51.3$, and $48.6 \%$ after tibial angioplasty and 81.5 , 76.8 , and $72.3 \%$ after tibial bypass surgery at 12,24 , and 36 months $(P<0.05)$. Of interest, despite these significant differences in patency rates, no significant differences in clinical outcomes were observed: limb salvage rates were $86.0,83.8$, and $82.4 \%$ in patients treated by angioplasty and $88.5,85.2$, and $82.3 \%$ after tibial bypass surgery at same intervals. Based on these findings, the tide over concept was established assuming that increased perfusion was mandatory for ulcer healing in CLI but not thereafter for maintaining skin integrity. Therefore, tibial arterial patency was considered to be of minor importance during mid- and long-term follow-up of CLI patients.

For several reasons, however, the validity of the methodological design and conclusion of that meta-analysis must be considered as limited. First, the sample size in the majority of studies included was small and ranged from 23 to 537 patients. Of note, $16 / 30(53.3 \%)$ studies had included less than 50 patients. In addition, 9/30 (30\%) studies included both CLI and patients with intermittent claudication. Thus, a substantial fraction of the patients $(548 / 2646,20.7 \%)$ did not suffer from limb-threatening ischemia. Accordingly, statistical power of both individual studies and the meta-analysis was limited. Second, a direct comparison of functional clinical outcomes is limited due to substantial variability of clinical end point definitions or the lack of clinical outcome reports at all $(20,33)$. Clinical end point definitions included subjective relief, freedom from CLI, improvement of clinical classification, and limb salvage $(8,32,40,41)$. Moreover, clinical outcomes were not reported throughout all studies but only in $26 / 30(86.7 \%)$ studies. Third, systematic patency evaluation was performed in only $9 / 30(30 \%)$ of studies included within the meta-analysis (17$19,24,33,37,38,44,45)$. Remarkably, patency was assessed by duplex sonography in $8 / 30(26.7 \%)$ studies and by angiography in only $1(3.3 \%)$ study in a total of $60 / 2646(2.3 \%)$ patients. Thus, the vast majority of patency evaluation was performed by duplex sonography, although its validity in tibial arteries is highly controversial (42). In addition, information on tibial patency was derived from the clinical need for repeated intervention in 4/30 (13.3\%) studies. Thus, arterial patency rates may have been overestimated utilizing this surrogate definition. Fourth, Romiti et al. published 3 -year outcomes, although only 16/30 (53.3\%) studies reported follow-up results beyond 24 months.

In addition to these limitations, the importance of tibial patency upon clinical outcomes was recently endorsed by various studies (10-13). It was shown that CLI patients require frequently target lesion revascularization (TLR) to maintain favorable clinical results subsequent to tibial angioplasty. Within the aforementioned study by Iida, TLR was necessary in $48 \%$ of patients with documented restenosis of the tibial target lesion in $73 \%$ at 12-month follow-up. In addition, the authors observed a prolonged time of wound healing in patients with tibial restenosis when compared to patients without restenosis: 127 versus 66 days $(P=0.02)$. The high prevalence of tibial TLR was recently corroborated by Baumann et al. within a consecutive series of 128 CLI patients undergoing tibial angioplasty (13). That group aimed for a comparison analyzing the clinically driven need for TLR versus target extremity revascularization (TER) after tibial angioplasty. After 1 year, TLR was performed in $41.6 \%$ and TER in $17.2 \%$ of patients. While adding proof to the high prevalence of TLR after tibial angioplasty, that observation moreover indicated that tibial restenosis is of greater clinical impact than progression of atherosclerotic disease as reflected by TER rates.

Moreover, Rastan et al. were the first to underline the importance of tibial patency within a randomized setting (11). The Yukon BTK trial randomly assigned a total of 161 patients comparing DES (82 patients) to BMS (79 patients) for tibial angioplasty in CLI. Primary clinical end point in the Yukon BTK trial was an event-free survival defined as freedom from target limb amputation, target vessel revascularization, myocardial infarction, and death. After a follow-up period of 1016 days, an event-free survival was attained in $65.8 \%$ in the DES group versus in $44.6 \%$ in the BMS group $(P=0.02)$. In line with clinical observations, primary tibial patency at 1 year was 80.6 versus $55.6 \%(P=0.004)$ when comparing DES with BMS (46).

Thus, in consideration of these substantial limitations behind the tide over concept and given observations from more recent clinical trials (11-13), the ultimate importance of tibial arterial patency subsequent to endovascular therapy remains to be determined. 
Table 1 | Summary of all studies analyzed within the meta-analysis of Romiti and coworkers.

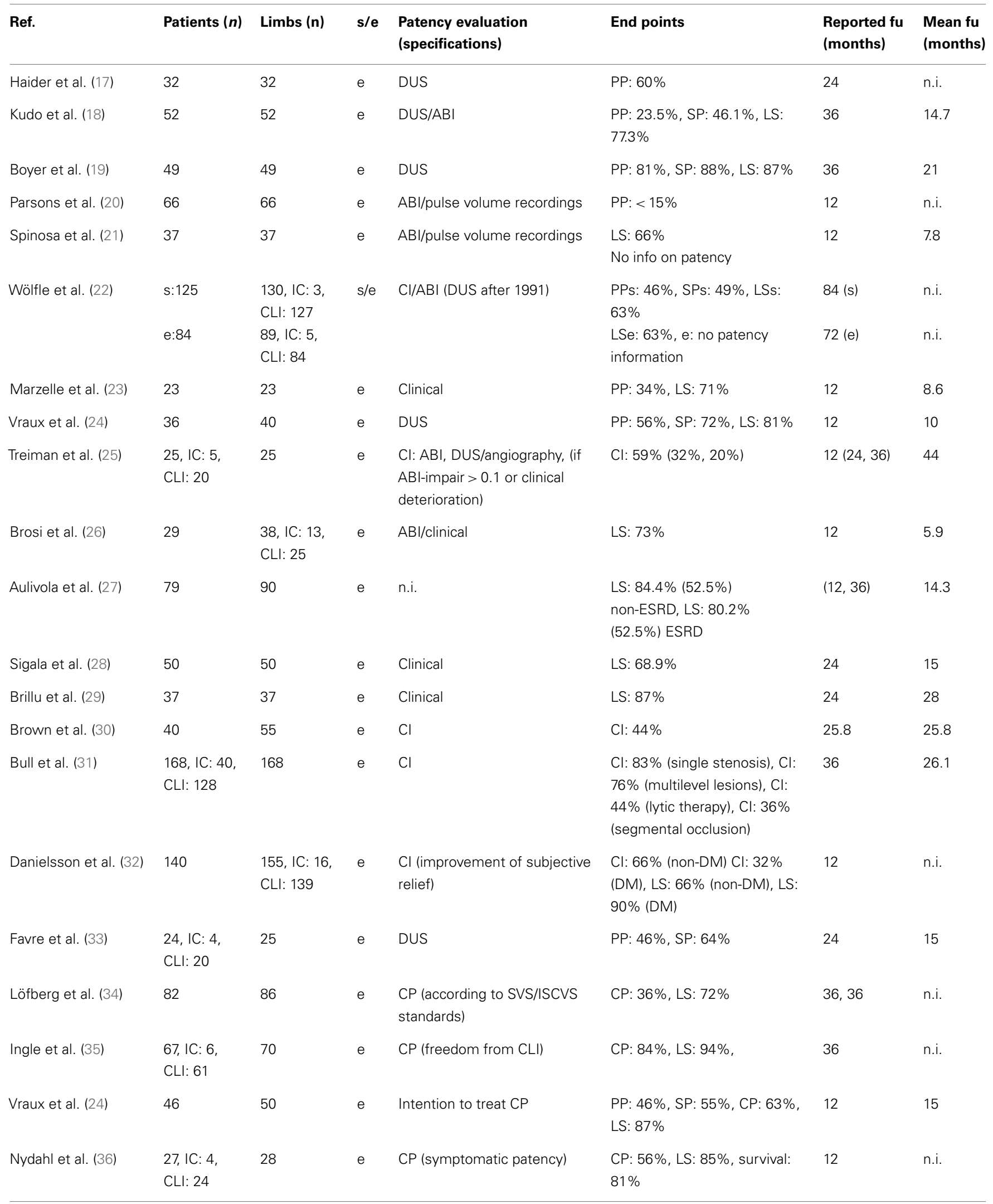


Table 1 | Continued

\begin{tabular}{|c|c|c|c|c|c|c|c|}
\hline Ref. & Patients (n) & Limbs (n) & s/e & $\begin{array}{l}\text { Patency evaluation } \\
\text { (specifications) }\end{array}$ & End points & $\begin{array}{l}\text { Reported fu } \\
\text { (months) }\end{array}$ & $\begin{array}{l}\text { Mean fu } \\
\text { (months) }\end{array}$ \\
\hline Tisi et al. (37) & 57 & 57 & $\mathrm{e}$ & $\begin{array}{l}\text { DUS: } n=26 \text {, Angiography: } \\
n=3 \text { (angiography if } \\
\text { ABl-impair }>0.1 \text { or clinical } \\
\text { deterioration) }\end{array}$ & PP: 27\%, SP: 33\%, LS: 88\% & 12 & n.i. \\
\hline Söder et al. (38) & 60 & 72 & e & Angiography & PP: $48 \%$, SP: $56 \%$, LS $80 \%$ & 18 & 10 \\
\hline Barton et al. (39) & 43 & n.i. & e & $\mathrm{Cl}$ (asymptomatic) & $\mathrm{Cl}: 60 \%$ & 36 & 28 \\
\hline Lazaris et al. (40) & 24 & 24 & e & Intention to treat & PP: $50 \%$, LS: $92 \%$ & 12 & n.i. \\
\hline Sivananthan et al. (41) & $\begin{array}{l}38, I C: 18 \\
\text { CLI: } 20\end{array}$ & 41 & e & $\begin{array}{l}\mathrm{Cl} \text { : (improvement } \geq 1 \\
\text { Fontaine category) }\end{array}$ & $\mathrm{Cl}: 58 \%$ & at last fu & 21 \\
\hline Faglia et al. (8) & $\begin{array}{l}\text { 537, s: } 117 \\
\text { e: } 420\end{array}$ & 537 & $\mathrm{~s} / \mathrm{e}$ & $\begin{array}{l}\mathrm{CP} \text { (no recurrence of } \\
\text { pain/ulcer) }\end{array}$ & CP, PTA: 78\%, Bypass: 77\% & 60 & 40 \\
\hline Bosiers et al. (42) & 443 & 443 & e & DUS & PP: $74.2 \%$, LS: 96.6\% & 12,12 & n.i. \\
\hline Schwarten (43) & 96 & 112 & e & n.i. & LS: $83 \%$ & 24 & n.i. \\
\hline Ascher et al. (44) & 30 & $\begin{array}{l}32, \text { IC: } 12 \\
\text { CLI: } 20\end{array}$ & e & DUS & LS: $100 \%, P P: 85 \%$ & 3 & 5.2 \\
\hline
\end{tabular}

Table 2 | Overview of randomized series comparing BMS with POBA for tibial revascularization in CLI patients.

\begin{tabular}{|c|c|c|c|c|c|c|}
\hline Ref. & $\begin{array}{l}\text { No. patients/ } \\
\text { lesions }\end{array}$ & $\begin{array}{l}\text { Lesion length } \\
(\mathrm{mm})\end{array}$ & Follow-up & $\begin{array}{l}\text { Patency evaluation } \\
\text { (number) }\end{array}$ & Patency (\%) & $\begin{array}{l}\text { Clinical } \\
\text { end points (\%) }\end{array}$ \\
\hline \multicolumn{7}{|c|}{ COMPLETED RANDOMIZED TRIALS ON BMS FOR BTK } \\
\hline Randon et al. (50) & $\begin{array}{l}35 / 38 \\
\text { BMS }^{\text {b }:} 16 \\
\text { PTA: } 22\end{array}$ & $\begin{array}{l}\text { BMS: } 22 \\
\text { PTA: } 39\end{array}$ & 12 months & Clinical patency & $\begin{array}{l}\text { BMS: } 66.0 \\
\text { PTA: } 79.5(P=\text { ni) }\end{array}$ & $\begin{array}{l}\text { LS } \\
\text { BMS } 92.7 \\
\text { PTA: } 90.0(P=0.76)\end{array}$ \\
\hline Brodmann et al. (48) & $\begin{array}{l}54 / 54 \\
\text { BMS }^{a}: 21 \\
\text { PTA: } 33\end{array}$ & $\begin{array}{l}\text { BMS: } 28 \\
\text { PTA: } 79\end{array}$ & 12 months & & $\begin{array}{l}\text { BMS: } 35.3 \\
\text { PTA: } 41.8(P=n s)\end{array}$ & $\begin{array}{l}\mathrm{Cl} \\
\text { BMS: } 64.7 \\
\text { PTA: } 81.5(P=\mathrm{ns})\end{array}$ \\
\hline
\end{tabular}

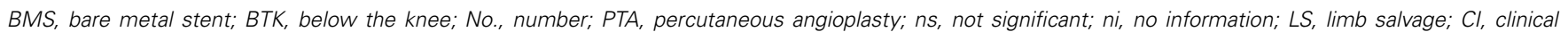
improvement (improvement $\geq 1$ category according to Rutherford classification); $P, P$ value; TLR, target lesion revascularization.

${ }^{a}$ Balloon-expandable BMS.

${ }^{b}$ Including balloon-expandable and self-expandable BMS.

c Self-expandable BMS.

\section{CURRENTLY AVAILABLE TECHNOLOGIES AIMED AT THE PREVENTION OF RESTENOSIS}

Given the excessive incidence of tibial arterial restenosis $(10,12$, $14,15)$ subsequent to POBA, various endovascular technologies have been assessed in the framework of clinical trials.

\section{BARE METAL STENTS}

Mechanical scaffolding as provided by a stent may be an ideal solution to address elastic recoil, an important contributor to restenosis in tibial arteries (47). The application of tibial BMS was assessed in various studies (48-50). However, no substantial 
benefit of BMS application when compared with POBA was observed within three randomized trials (48-50) (Table 2). Based on these observations, it may be assumed that neointimal proliferation induced by BMS outweighs the potential benefit of mechanical scaffolding in the prevention of restenosis induced by elastic recoil.

\section{DRUG-ELUTING STENTS}

Given the above-outlined drawbacks of BMS in tibial interventions, great hope was attributed to DES technology. The principle of DES is to provide mechanical scaffolding but with a minimum of neointimal proliferation based on the antiproliferative coating. Four randomized trials compared DES versus POBA or BMS for tibial angioplasty $(46,51-53)$ (Table 3$)$. Whilst the Yukon trial compared DES with BMS (46), the remaining randomized studies compared DES to POBA (51-53). Without exception, DES was superior when compared with BMS/POBA for tibial angioplasty in respect to patency and the need for repeated TLR. In addition, DES was shown to improve event-free survival rates when compared with BMS as shown within the aforementioned Yukon trial (11).

Of note, however, tibial arterial lesion lengths of patients included in all randomized DES trials were $\leq 35 \mathrm{~mm}$. Within a consecutive series, Baumann et al. analyzed tibial lesion morphology in 105 CLI patients undergoing tibial angioplasty (16). Thereby, a mean lesion length of $87 \mathrm{~mm}$ was observed for stenotic and $124 \mathrm{~mm}$ for occlusive tibial PAD. According to these morphological findings, only $11 \%$ of that study population would have qualified for participation within the above-mentioned randomized DES trials. Thus, currently available coronary DES is applicable to only a minority of CLI patients treated in everyday clinical practice.

Table 3 | Overview of randomized trials comparing DES versus BMS or POBA for BTK angioplasty.

\begin{tabular}{|c|c|c|c|c|c|c|c|c|c|}
\hline Reference & Devices & $\begin{array}{l}\text { Rutherford } \\
\text { categories }\end{array}$ & $\begin{array}{l}\text { Renal } \\
\text { insufficiency }\end{array}$ & $\begin{array}{l}\text { Inclusion } \\
\text { criteria }\end{array}$ & $\begin{array}{l}\text { Patients } \\
\text { (n) }\end{array}$ & $\begin{array}{l}\text { Follow-up } \\
\text { (months) }\end{array}$ & Final LL & End point & Results \\
\hline Yukon (46) & $\begin{array}{l}\text { DES }{ }^{\circ} \text { versus } \\
\text { BMS ( }{ }^{\circ} \text { Yukon, } \\
\text { Translumina, } \\
\text { Hechingen, } \\
\text { Germany) }\end{array}$ & $2-5$ & n.i. & $\begin{array}{l}\text { de novo } \\
\text { lesions steno- } \\
\text { sis }>70 \% \\
\mathrm{LL}<45 \mathrm{~mm}\end{array}$ & 161 & 12 & $31 \pm 9$ & $\begin{array}{l}\text { Restenosis } \\
(>50 \%) \\
\text { (a) DUS } \\
\text { (PSVR > 2.4) } \\
\text { (b) Angiography }\end{array}$ & $\begin{array}{l}\text { Primary } \\
\text { patency } \\
\text { DES: } 80.6 \% \\
\text { BMS: } 55.6 \% \\
(P=0.004) \\
\text { Secondary } \\
\text { patency } \\
\text { DES: } 91.9 \% \\
\text { BMS: } 71.4 \% \\
(P: 0.005)\end{array}$ \\
\hline $\begin{array}{l}\text { Destiny } \\
(52)\end{array}$ & $\begin{array}{l}\text { DES }{ }^{\circ} \text { versus BMS } \\
\left({ }^{\circ} \text { Xience } V \text { stent }\right)\end{array}$ & 4,5 & n.i. & $\begin{array}{l}\text { de novo steno- } \\
\text { sis }>50 \% \\
\text { LL }<40 \mathrm{~mm}\end{array}$ & 140 & 12 & n.i. & $\begin{array}{l}\text { Restenosis > } \\
50 \% \text { by } \\
\text { angiography }\end{array}$ & $\begin{array}{l}\text { Primary } \\
\text { patency } \\
\text { DES: } 85 \% \\
\text { BMS: } 54 \% \\
(P=0.0001)\end{array}$ \\
\hline $\begin{array}{l}\text { Falkowski } \\
\text { (53) }\end{array}$ & $\begin{array}{l}\text { DES }{ }^{\circ} \text { versus BMS } \\
\left({ }^{\circ} \text { Cipher Cordis }\right. \\
\text { Europa N.V.) }\end{array}$ & $3-5$ & n.i. & $\begin{array}{l}\text { de novo steno- } \\
\text { sis }>60 \%, \mathrm{LL} \\
5-30 \mathrm{~mm}\end{array}$ & 50 & 6 & 17.8 & $\begin{array}{l}\text { PE: Resteno- } \\
\text { sis }>50 \% \text { by } \\
\text { angiography }\end{array}$ & $\begin{array}{l}\text { Primary } \\
\text { patency } \\
\text { DES: } 16 \% \\
\text { BMS: } 76 \% \\
(P=0.001) \\
\text { TLR } \\
\text { DES: } 12 \% \\
\text { BMS: } 56 \% \\
(P<0.05)\end{array}$ \\
\hline \multicolumn{10}{|c|}{ RANDOMIZEDTRIALS ON DES VERSUS POBA FOR BTK ANGIOPLASTY } \\
\hline $\begin{array}{l}\text { Achilles } \\
\text { (51) }\end{array}$ & $\begin{array}{l}\text { DES }{ }^{\circ} \text { versus } \\
\text { POBA ( }{ }^{\circ} \text { Cipher } \\
\text { Select, Cordis } \\
\text { Cooperation, } \\
\text { USA) }\end{array}$ & $3-5$ & $\begin{array}{l}\text { exclusion: } \\
\text { creatinine > } \\
2.5 \mathrm{mg} / \mathrm{dl}\end{array}$ & $\begin{array}{l}\text { de novo and } \\
\text { restenotic } \\
\text { native steno- } \\
\text { sis }>70 \% \text {, } \\
\text { LL }<120 \mathrm{~mm}\end{array}$ & $\begin{array}{l}200(99 \\
\text { versus } \\
101)\end{array}$ & 12 & $27 \pm 21$ & $\begin{array}{l}\text { Restenosis by } \\
\text { angiography }\end{array}$ & $\begin{array}{l}\text { Primary } \\
\text { patency } \\
\text { DES: } 77.6 \% \\
\text { POBA: } 58.1 \%\end{array}$ \\
\hline
\end{tabular}

n, number; n.i., no information; LL, lesion length; DUS, duplex ultrasound; PSVR, peak systolic velocity ratio; DES, drug-eluting stent; BMS, bare metal stent; TLR, target lesion revascularization; PE, primary end point; SE, secondary end point; POBA, plain-old balloon angioplasty. 
Table 4 | Overview of ongoing/not completed randomized trials on DEB versus BMS or POBA for BTK angioplasty

\begin{tabular}{|c|c|c|c|c|c|c|}
\hline Study name & Devices & $\begin{array}{l}\text { Rutherford } \\
\text { categories }\end{array}$ & $\begin{array}{l}\text { Predefined } \\
\text { LL (mm) }\end{array}$ & $\begin{array}{l}\text { Patients } \\
\text { (n) }\end{array}$ & $\begin{array}{l}\text { Follow-up } \\
\text { (months) }\end{array}$ & End points \\
\hline \multicolumn{7}{|c|}{ PLANNED/ONGOING RANDOMIZEDTRIALS ON DEB FOR BTK ANGIOPLASTY } \\
\hline Piccolo & DEB versus POBA & $3-5$ & $15-150$ & 114 & 6 & Late lumen loss (angiography) \\
\hline InPact Deep ${ }^{a}$ & DEB versus POBA & $4-6$ & $<100$ & 450 & 12 & $\begin{array}{l}\text { Clinically driven TLR, } \\
\text { restenosis (angiography) }\end{array}$ \\
\hline Euro Canal ${ }^{b}$ & DEB versus POBA & $4-6$ & $10-270$ & 120 & 6 & Late lumen loss (angiography) \\
\hline
\end{tabular}

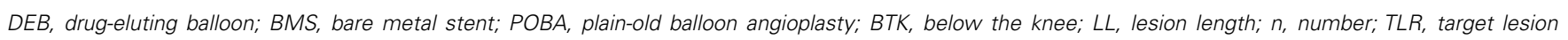
revascularization; DUS, duplex ultrasound.

a Study terminated early based on safety concerns.

bStudy terminated early based on strategic company decision, no safety concerns.

\section{DRUG-ELUTING BALLOONS}

DEB technology was introduced with the intention of reducing neointimal proliferation. First, by limiting the mechanical irritation to the duration of balloon inflation, and second, by the application of an antiproliferative substance during the endothelial injury phase induced by angioplasty. According to first observations, the application of DEB may reduce restenosis and the need for repeated revascularization when compared with POBA for tibial revascularization $(10,54)$.

Within a non-randomized study setting, Schmidt et al. evaluated the application of DEB for tibial revascularization in 104 patients (CLI: $82.6 \%$, severe claudication: $17.4 \%$, limbs: $\mathrm{n}=109$ ) (54). Binary restenosis was evaluated using angiography and defined as a $>50 \%$ reduction of lumen diameter. After 3 months, binary restenosis after DEB was observed in $27.4 \%$. Within a similar cohort of historic control patients at the same center undergoing tibial POBA, restenosis was reported in $68.8 \%$ after 3 months (54). According to this, DEB was shown to reduce tibial restenosis by around $60 \%$ when compared with POBA and, thus, great hope was placed on DEB technology aimed at improving tibial patency. The superiority of DEB over POBA in tibial arteries was furthermore shown by Liistro et al. who were the first to report results from a randomized trial (10). Within the DEBATE-BTK trial, Liistro and coworkers analyzed 132 patients for tibial angioplasty randomly assigned for 67 DEB and 65 POBA. Mean lesion length was $129 \mathrm{~mm}$ in patients treated with DEB and $131 \mathrm{~mm}$ treated with POBA $(P=0.9)$. Primary end point in that trial was binary restenosis defined $>50 \%$ after 12 months by angiography ( $>90 \%$ of patients) and/or duplex sonography for the remaining. Secondary clinical end points were the incidence of TLR and amputation. Binary restenosis was $27 \%$ in the DEB and $74 \%$ in the POBA group $(P<0.001)$. In addition, the need for secondary TLR was lower in patients treated with DEB compared to those treated with POBA (18 versus $43 \%, P=0.002$ ).

Of note, for technical reasons, operators within most of the randomized and observational trials including the DEBATE-BTK trial were not blinded to treatment allocation. This may have influenced the decision of performing TLR and may serve as an explanation for the wide range of TLR rates. During 1-year follow-up, amputation was necessary in one patient in the POBA group and none in the DEB group $(P=0.9)$. In the meantime, results from further randomized trials are awaited (Table 4). Of these, the Euro Canal trial was terminated early due to strategic reorientation of the company. A second randomized trial performed was the InPact Deep trial, which was finished but upon completion the company withdrew the DEB of investigation from the market. This was based on the 12-month results with lacking efficacy of DEB and moreover higher major amputation rates for DEB (8.8\%) when compared to POBA $(3.6 \%, P=0.08)$.

\section{CONCLUSION}

In contrast to earlier observations, patency appears to affect clinical outcomes in CLI patients, and thus, remains the major drawback of tibial arterial angioplasty. DES and DEB were shown to improve tibial patency but both with specific limitations. Accordingly, currently applied and evaluated DES for tibial revascularization do not address infrapopliteal lesion morphology. While DEB technology complies well with tibial lesion morphology in CLI patients, it may not address acute elastic recoil, an important contributor to tibial restenosis. Further studies assessing anti-restenosis concepts specifically dedicated to the unique requirements of complex tibial arterial obstructions are warranted.

\section{REFERENCES}

1. Lepantalo M, Matzke S. Outcome of unreconstructed chronic critical leg ischaemia. Eur J Vasc Endovasc Surg (1996) 11:153-7. doi:10.1016/S10785884(96)80044-X

2. Norgren L, Hiatt WR, Dormandy JA, Nehler MR, Harris KA, Fowkes FG, et al. Inter-society consensus for the management of peripheral arterial disease (TASC II). J Vasc Surg (2007) 45(Suppl S):S5-67. doi:10.1016/j.jvs.2006.12.037

3. Diehm N, Pattynama PM, Jaff MR, Cremonesi A, Becker GJ, Hopkins LN, et al. Clinical endpoints in peripheral endovascular revascularization trials: a case for standardized definitions. Eur J Vasc Endovasc Surg (2008) 36:409-19. doi:10.1016/j.ejvs.2008.06.020

4. Lo RC, Darling J, Bensley RP, Giles KA, Dahlberg SE, Hamdan AD, et al. Outcomes following infrapopliteal angioplasty for critical limb ischemia. J Vasc Surg (2013) 57:1455-63. doi:10.1016/j.jvs.2012.10.109

5. Adam DJ, Beard JD, Cleveland T, Bell J, Bradbury AW, Forbes JF, et al. Bypass versus angioplasty in severe ischaemia of the leg (BASIL): multicentre, randomised controlled trial. Lancet (2005) 366:1925-34. doi:10.1016/S01406736(05)67704-5

6. European Stroke O, Tendera M, Aboyans V, Bartelink ML, Baumgartner I, Clement D, et al. ESC guidelines on the diagnosis and treatment of peripheral artery diseases: document covering atherosclerotic disease of extracranial 
carotid and vertebral, mesenteric, renal, upper and lower extremity arteries: the task force on the diagnosis and treatment of peripheral artery diseases of the European Society of Cardiology (ESC). Eur Heart J (2011) 32:2851-906. doi:10.1093/eurheartj/ehr211

7. Romiti M, Albers M, Brochado-Neto FC, Durazzo AE, Pereira CA, De Luccia N. Meta-analysis of infrapopliteal angioplasty for chronic critical limb ischemia. $J$ Vasc Surg (2008) 47:975-81. doi:10.1016/j.jvs.2008.01.005

8. Faglia E, Clerici G, Clerissi J, Gabrielli L, Losa S, Mantero M, et al. Early and five-year amputation and survival rate of diabetic patients with critical limb ischemia: data of a cohort study of 564 patients. Eur J Vasc Endovasc Surg (2006) 32:484-90. doi:10.1016/j.ejvs.2006.03.006

9. Ferraresi R, Centola M, Ferlini M, Da Ros R, Caravaggi C, Assaloni R, et al. Long-term outcomes after angioplasty of isolated, below-the-knee arteries in diabetic patients with critical limb ischaemia. Eur J Vasc Endovasc Surg (2009) 37:336-42. doi:10.1016/j.ejvs.2008.12.001

10. Liistro F, Porto I, Angioli P, Grotti S, Ricci L, Ducci K, et al. Drug-eluting balloon in peripheral intervention for below the knee angioplasty evaluation (DEBATEBTK): a randomized trial in diabetic patients with critical limb ischemia. Circulation (2013) 128:615-21. doi:10.1161/CIRCULATIONAHA.113.001811

11. Rastan A, Brechtel K, Krankenberg H, Zahorsky R, Tepe G, Noory E, et al. Sirolimus-eluting stents for treatment of infrapopliteal arteries reduce clinical event rate compared to bare-metal stents: long-term results from a randomized trial. J Am Coll Cardiol (2012) 60:587-91. doi:10.1016/j.jacc.2012.04.035

12. Iida O, Soga Y, Kawasaki D, Hirano K, Yamaoka T, Suzuki K, et al. Angiographic restenosis and its clinical impact after infrapopliteal angioplasty. Eur J Vasc Endovasc Surg (2012) 44:425-31. doi:10.1016/j.ejvs.2012.07.017

13. Baumann F, Bloesch S, Engelberger RP, Makaloski V, Fink H, Do DD, et al. Clinically-driven need for secondary interventions after endovascular revascularization of tibial arteries in patients with critical limb ischemia. J Endovasc Ther (2013) 20:707-13. doi:10.1583/13-4375MR.1

14. Rastan A, Noory E, Zeller T. Drug-eluting stents for treatment of focal infrapopliteal lesions. Vasa (2012) 41:90-5. doi:10.1024/0301-1526/a000170

15. Schmidt A, Ulrich M, Winkler B, Klaeffling C, Bausback Y, Braunlich S, et al. Angiographic patency and clinical outcome after balloon-angioplasty for extensive infrapopliteal arterial disease. Catheter Cardiovasc Interv (2010) 76:1047-54. doi:10.1002/ccd.22658

16. Baumann F, Engelberger RP, Willenberg T, Do DD, Kalka C, Baumgartner I, et al. Infrapopliteal lesion morphology in patients with critical limb ischemia: implications for the development of anti-restenosis technologies. J Endovasc Ther (2013) 20:149-56. doi:10.1583/1545-1550-20.2.149

17. Haider SN, Kavanagh EG, Forlee M, Colgan MP, Madhavan P, Moore DJ, et al. Two-year outcome with preferential use of infrainguinal angioplasty for critical ischemia. J Vasc Surg (2006) 43:504-12. doi:10.1016/j.jvs.2005.11.016

18. Kudo T, Chandra FA, Ahn SS. The effectiveness of percutaneous transluminal angioplasty for the treatment of critical limb ischemia: a 10-year experience. $J$ Vasc Surg (2005) 41:423-35. doi:10.1016/j.jvs.2004.11.041

19. Boyer L, Therre T, Garcier JM, Perez N, Ravel A, Privat C, et al. Infrapopliteal percutaneous transluminal angioplasty for limb salvage. Acta Radiol (2000) 41:73-7. doi:10.1080/028418500127344795

20. Parsons RE, Suggs WD, Lee JJ, Sanchez LA, Lyon RT, Veith FJ. Percutaneous transluminal angioplasty for the treatment of limb threatening ischemia: do the results justify an attempt before bypass grafting? J Vasc Surg (1998) 28:1066-71. doi:10.1016/S0741-5214(98)70033-3

21. Spinosa DJ, Leung DA, Matsumoto AH, Bissonette EA, Cage D, Harthun NL, et al. Percutaneous intentional extraluminal recanalization in patients with chronic critical limb ischemia. Radiology (2004) 232:499-507. doi:10.1148/ radiol.2322030729

22. Wolfle KD, Bruijnen H, Reeps C, Reutemann S, Wack C, Campbell P, et al. Tibioperoneal arterial lesions and critical foot ischaemia: successful management by the use of short vein grafts and percutaneous transluminal angioplasty. Vasa (2000) 29:207-14. doi:10.1024/0301-1526.29.3.207

23. Marzelle J, Cormier F, Fichelle JM, Cormier JM. [Distal arteritis of the legs: endovascular treatment]. J Mal Vasc (1994) 19(Suppl A):170-3.

24. Vraux H, Hammer F, Verhelst R, Goffette P, Vandeleene B. Subintimal angioplasty of tibial vessel occlusions in the treatment of critical limb ischaemia: mid-term results. Eur J Vasc Endovasc Surg (2000) 20:441-6. doi:10.1053/ejvs.2000.1200

25. Treiman GS, Treiman RL, Ichikawa L, Van Allan R. Should percutaneous transluminal angioplasty be recommended for treatment of infrageniculate popliteal artery or tibioperoneal trunk stenosis? J Vasc Surg (1995) 22:457-63. doi:10.1016/S0741-5214(95)70015-3

26. Brosi P, Baumgartner I, Silvestro A, Do DD, Mahler F, Triller J, et al. Below-theknee angioplasty in patients with end-stage renal disease. J Endovasc Ther (2005) 12:704-13. doi:10.1583/05-1638MR.1

27. Aulivola B, Gargiulo M, Bessoni M, Rumolo A, Stella A. Infrapopliteal angioplasty for limb salvage in the setting of renal failure: do results justify its use? Ann Vasc Surg (2005) 19:762-8. doi:10.1007/s10016-005-7970-6

28. Sigala F, Menenakos C, Sigalas P, Baunach C, Langer S, Papalambros E, et al. Transluminal angioplasty of isolated crural arterial lesions in diabetics with critical limb ischemia. Vasa (2005) 34:186-91. doi:10.1024/0301-1526.34.3.186

29. Brillu C, Picquet J, Villapadierna F, Papon X, L'Hoste P, Jousset Y, et al. Percutaneous transluminal angioplasty for management of critical ischemia in arteries below the knee. Ann Vasc Surg (2001) 15:175-81. doi:10.1007/s100160010044

30. Brown KT, Moore ED, Getrajdman GI, Saddekni S. Infrapopliteal angioplasty: long-term follow-up. J Vasc Interv Radiol (1993) 4:139-44. doi:10.1016/S10510443(93)71836-9

31. Bull PG, Mendel H, Hold M, Schlegl A, Denck H. Distal popliteal and tibioperoneal transluminal angioplasty: long-term follow-up. J Vasc Interv Radiol (1992) 3:45-53. doi:10.1016/S1051-0443(92)72185-X

32. Danielsson G, Albrechtsson U, Norgren L, Danielsson P, Ribbe E, Thorne J, et al. Percutaneous transluminal angioplasty of crural arteries: diabetes and other factors influencing outcome. Eur J Vasc Endovasc Surg (2001) 21:432-6. doi:10.1053/ejvs.2001.1351

33. Favre JP, Do Carmo G, Adham M, Gournier JP, Barral X. Results of transluminal angioplasty of infra-popliteal arteries. J Cardiovasc Surg (1996) 37:33-7.

34. Lofberg AM, Lorelius LE, Karacagil S, Westman B, Almgren B, Berqgvist D. The use of below-knee percutaneous transluminal angioplasty in arterial occlusive disease causing chronic critical limb ischemia. Cardiovasc Intervent Radiol (1996) 19:317-22. doi:10.1007/BF02570182

35. Ingle H, Nasim A, Bolia A, Fishwick G, Naylor R, Bell PR, et al. Subintimal angioplasty of isolated infragenicular vessels in lower limb ischemia: longterm results. J Endovasc Ther (2002) 9:411-6. doi:10.1583/1545-1550(2002) 009<0481:LTROEA > 2.0.CO;2

36. Nydahl S, Hartshorne T, Bell PR, Bolia A, London NJ. Subintimal angioplasty of infrapopliteal occlusions in critically ischaemic limbs. Eur J Vasc Endovasc Surg (1997) 14:212-6. doi:10.1016/S1078-5884(97)80194-3

37. Tisi PV, Mirnezami A, Baker S, Tawn J, Parvin SD, Darke SG. Role of subintimal angioplasty in the treatment of chronic lower limb ischaemia. Eur J Vasc Endovasc Surg (2002) 24:417-22. doi:10.1053/ejvs.2002.1754

38. Soder HK, Manninen HI, Jaakkola P, Matsi PJ, Rasanen HT, Kaukanen E, et al. Prospective trial of infrapopliteal artery balloon angioplasty for critical limb ischemia: angiographic and clinical results. J Vasc Interv Radiol (2000) 11:1021-31. doi:10.1016/S1051-0443(07)61332-3

39. Barton P, Karnel F, Schurawitzki H, Kretschmer G, Polterauer P. [Long term results of interventional treatment of arteries below the knee]. Vasa Suppl (1990) 30:181-5.

40. Lazaris AM, Salas C, Tsiamis AC, Vlachou PA, Bolia A, Fishwick G, et al. Factors affecting patency of subintimal infrainguinal angioplasty in patients with critical lower limb ischemia. Eur J Vasc Endovasc Surg (2006) 32:668-74. doi:10.1016/j.ejvs.2006.07.016

41. Sivananthan UM, Browne TF, Thorley PJ, Rees MR. Percutaneous transluminal angioplasty of the tibial arteries. Br J Surg (1994) 81:1282-5. doi:10.1002/bjs. 1800810907

42. Bosiers M, Peeters P, D’Archambeau O, Hendriks J, Pilger E, Duber C, et al. AMS INSIGHT - absorbable metal stent implantation for treatment of belowthe-knee critical limb ischemia: 6-month analysis. Cardiovasc Intervent Radiol (2009) 32:424-35. doi:10.1007/s00270-008-9472-8

43. Schwarten DE. Clinical and anatomical considerations for nonoperative therapy in tibial disease and the results of angioplasty. Circulation (1991) 83:I86-90.

44. Ascher E, Marks NA, Hingorani AP, Schutzer RW, Mutyala M. Duplex-guided endovascular treatment for occlusive and stenotic lesions of the femoralpopliteal arterial segment: a comparative study in the first 253 cases. J Vasc Surg (2006) 44:1230-7. doi:10.1016/j.jvs.2006.08.025

45. Bosiers M, Hart JP, Deloose K, Verbist J, Peeters P. Endovascular therapy as the primary approach for limb salvage in patients with critical limb ischemia: experience with 443 infrapopliteal procedures. Vascular (2006) 14:63-9. doi:10. 2310/6670.2006.00014 
46. Rastan A, Tepe G, Krankenberg H, Zahorsky R, Beschorner U, Noory E, et al. Sirolimus-eluting stents vs. bare-metal stents for treatment of focal lesions in infrapopliteal arteries: a double-blind, multi-centre, randomized clinical trial. Eur Heart J (2011) 32:2274-81. doi:10.1093/eurheartj/ehr144

47. Baumann F, Fust J, Engelberger RP, Huegel U, Do-Dai D, Willenberg T, et al. Early recoil after balloon angioplasty of tibial artery obstructions in patients with critical limb ischemia. J Endovasc Ther (2014) 21:44-51. doi:10.1583/13-4486MR.1

48. Brodmann M, Froehlich H, Dorr A, Gary T, Portugaller RH, Deutschmann $\mathrm{H}$, et al. Percutaneous transluminal angioplasty versus primary stenting in infrapopliteal arteries in critical limb ischemia. Vasa (2011) 40:482-90. doi:10. 1024/0301-1526/a000152

49. Rand T, Basile A, Cejna M, Fleischmann D, Funovics M, Gschwendtner M, et al. PTA versus carbofilm-coated stents in infrapopliteal arteries: pilot study. Cardiovasc Intervent Radiol (2006) 29:29-38. doi:10.1007/s00270-005-0276-9

50. Randon C, Jacobs B, De Ryck F, Vermassen F. Angioplasty or primary stenting for infrapopliteal lesions: results of a prospective randomized trial. Cardiovasc Intervent Radiol (2010) 33:260-9. doi:10.1007/s00270-009-9765-6

51. Scheinert D, Katsanos K, Zeller T, Koppensteiner R, Commeau P, Bosiers M, et al. A prospective randomized multicenter comparison of balloon angioplasty and infrapopliteal stenting with the sirolimus-eluting stent in patients with ischemic peripheral arterial disease: 1-year results from the ACHILLES trial. J Am Coll Cardiol (2012) 60:2290-5. doi:10.1016/j.jacc.2012.08.989

52. Bosiers M, Scheinert D, Peeters P, Torsello G, Zeller T, Deloose K, et al. Randomized comparison of everolimus-eluting versus bare-metal stents in patients with critical limb ischemia and infrapopliteal arterial occlusive disease. J Vasc Surg (2012) 55:390-8. doi:10.1016/j.jvs.2011.07.099

53. Falkowski A, Poncyljusz W, Wilk G, Szczerbo-Trojanowska M. The evaluation of primary stenting of sirolimus-eluting versus bare-metal stents in the treatment of atherosclerotic lesions of crural arteries. Eur Radiol (2009) 19:966-74. doi:10.1007/s00330-008-1225-1

54. Schmidt A, Piorkowski M, Werner M, Ulrich M, Bausback Y, Braunlich S, et al. First experience with drug-eluting balloons in infrapopliteal arteries: restenosis rate and clinical outcome. J Am Coll Cardiol (2011) 58:1105-9. doi:10.1016/j.jacc.2011.05.034

Conflict of Interest Statement: Nicolas Diehm was the Principal Investigator for Switzerland of the Euro Canal trial and received consulting honoraria from Medrad. This trial, however, was terminated early due to strategical reorientation of the company. Thereafter, Nicolas Diehm has no more financial disclosures or conflicts of interest to report. The remaining authors have neither financial disclosures nor a conflict of interest to state.

Received: 12 September 2014; accepted: 16 December 2014; published online: 07 January 2015.

Citation: Baumann F, Ozdoba C, Gröchenig E and Diehm N (2015) The importance of patency in patients with critical limb ischemia undergoing endovascular revascularization for infrapopliteal arterial disease. Front. Cardiovasc. Med. 1:17. doi: $10.3389 / f \mathrm{cvm} .2014 .00017$

This article was submitted to Vascular Medicine, a section of the journal Frontiers in Cardiovascular Medicine.

Copyright (C) 2015 Baumann, Ozdoba, Gröchenig and Diehm. This is an open-access article distributed under the terms of the Creative Commons Attribution License (CC $B Y)$. The use, distribution or reproduction in other forums is permitted, provided the original author(s) or licensor are credited and that the original publication in this journal is cited, in accordance with accepted academic practice. No use, distribution or reproduction is permitted which does not comply with these terms. 